\title{
Effects of level of dietary copper sulphate and period of feeding on the laying, domestic fowl, with special reference to tissue mineral content
}

\author{
BY MARY H. STEVENSON AND N. JACKSON \\ Agricultural and Food Chemistry Research Division, \\ Department of Agriculture for Northern Ireland, \\ and The Queen's University of Belfast, Newforge Lane, \\ Belfast BT9 5 PX, Northern Ireland \\ (Received 9 July 1979 - Accepted I September 1979)
}

1. A cereal-based diet containing $7.6 \mathrm{mg}$ copper $/ \mathrm{kg}$ was fed ad lib. to laying hens for up to $48 \mathrm{~d}$. Four other groups were given the control diet to which was added hydrated copper sulphate to provide 250,500 , 1000 and $2000 \mathrm{mg}$ added $\mathrm{Cu} / \mathrm{kg}$.

2. Hens were killed on day 0 and after 3,6,12, 24 and $48 \mathrm{~d}$. Records were kept of body-weight, food consumption, egg production and egg weight.

3. After slaughter blood haemoglobin, packed cell volume, serum $\mathrm{Cu}$ and aspartate aminotransferase (AAT; EC 2.6.I. I) were measured. The liver, kidneys, a sample of breast muscle, oviduct, ovary and gizzard were weighed. Gizzard, spleen, liver and kidney tissue were examined histologically.

4. The $\mathrm{Cu}$, zinc and iron concentrations of liver, kidneys and breast muscle and the manganese concentrations of liver and kidneys were determined.

5. Body-weight loss occurred at $500-2000 \mathrm{mg}$ added $\mathrm{Cu} / \mathrm{kg}$ diet. Egg production was depressed by level of added $\mathrm{Cu}$ and period of time on the Cu-containing diets.

6. Mean liver, kidney, oviduct and ovarian weights per unit body-weight were depressed by $\mathrm{Cu}$ in the diet and the effect increased with period of time on the diets. Mean gizzard weight per unit body-weight was increased by dietary added $\mathrm{Cu}$ and by time.

7. $\mathrm{Cu}$ concentrations in the liver were increased by dietary level of added $\mathrm{Cu}$ and period of time on the diet. $\mathrm{Zn}$ concentration in liver increased at 1000 and $2000 \mathrm{mg}$ added $\mathrm{Cu} / \mathrm{kg}$ diet and liver $\mathrm{Fe}$ concentration was increased at these levels. Histological examination of the gizzard indicated that the $\mathrm{Cu}$ content of the gizzard lining increased with dietary added $\mathrm{Cu}$.

Copper has been used as a growth stimulant in pig feeding for many years (Barber $e t$ al. I955) but knowledge of its effects on poultry performance is limited (Agricultural Research Council, I975).

The effects of adding $\mathrm{Cu}$ to broiler diets have been investigated (Fisher et al. 1972; Fisher, 1973). In more recent studies the effects of short and long term feeding of $\mathrm{Cu}$ as sulphate $\left(\mathrm{CuSO}_{4} \cdot 5 \mathrm{H}_{2} \mathrm{O}\right)$ in the diet of laying hens have been reported (Jackson, 1977; Jackson et al. 1979). The longer term studies (Jackson et al. 1979) used up to $800 \mathrm{mg}$ added $\mathrm{Cu} / \mathrm{kg}$ diet and did not cause any obvious pathological effects.

The present experiment was initiated mainly in order to observe the rate at which the performance of laying hens, in terms of egg production, body-weight change, and the mineral content of some specific tissues would be affected by feeding diets supplemented with $\mathrm{CuSO}_{4} \cdot 5 \mathrm{H}_{2} \mathrm{O}$ supplying up to $2000 \mathrm{mg}$ added $\mathrm{Cu} / \mathrm{kg}$ diet. A brief report of some initial results has already been presented (Stevenson \& Jackson, 1979).

\section{EX PERIMENTAL}

White light hybrid (Shaver 288) point-of-lay hens ( 156 birds, 17 weeks old) were placed in galvanized-iron cages fitted with individual feeders and nipple drinkers. The initial lighting regimen of $\mathrm{I} \mathrm{h}$ h light and $\mathrm{I} 3 \mathrm{~h}$ darkness was changed weekly until $\mathrm{I} 7 \mathrm{~h}$ light and $7 \mathrm{~h}$ darkness 
was achieved at the commencement of the experiment: this lighting programme was maintained until the experiment ended. At 24 weeks of age, when all the hens had been laying for at least 2 weeks, they were randomly allocated to a pre-experimental group of six birds and to five treatment groups each containing thirty birds. The birds of the preexperimental group were killed at the start of the experiment.

The diets, fed ad lib., were the control diet, the composition of which has been reported by Jackson (1977), alone or with $\mathrm{Cu}$ added as $\mathrm{CuSO}_{4} \cdot 5 \mathrm{H}_{2} \mathrm{O}$ at $(\mathrm{mg} / \mathrm{kg}) 250,500$, 1000 and 2000. The $\mathrm{Cu}$ salt was finely ground as specified by Jackson (1977). The control diet contained (/kg): $173 \mathrm{~g}$ crude protein (nitrogen $\times 6.25$ ), $7.6 \mathrm{mg} \mathrm{Cu}$, $136 \mathrm{mg}$ zinc, $415 \mathrm{mg} \mathrm{Fe}, 32 \mathrm{~g}$ calcium, $5 \cdot 2 \mathrm{~g}$ phosphorus and had a calculated metabolizable energy content of I I. 4 $\mathrm{MJ} / \mathrm{kg}$.

Six hens, selected at random from each treatment, were killed $3,6,12,24$ and $48 \mathrm{~d}$ after the start of the experiment. Individual body-weights were recorded at the start of the experiment and at slaughter. Records were kept of food consumption, daily egg production and egg weight.

The birds were killed by decapitation and blood haemoglobin (Hb) and packed cell volume (PCV) determined. Serum $\mathrm{Cu}$ was determined by the method of Ichida $\&$ Nobuoka (I969) and aspartate aminotransferase (AAT; EC 2.6. I I) by the method of Bergmeyer \& Bernt (I965). The results were expressed in international units, where one unit represents the oxidation of I $\mu \mathrm{mol} \mathrm{NADPH} / \mathrm{min}$ at $37^{\circ}$. The fresh weights of the ovary, oviduct and gizzard were recorded. The liver, kidneys and a portion of breast muscle were weighed and oven-dried at $100^{\circ}$ before chemical analyses. Portions of the gizzard, spleen, liver and kidneys were examined histologically for the presence of $\mathrm{Cu}$ (Lindquist, I969) and glycogen as previously described (Jackson et al. 1979). The $\mathrm{Cu}, \mathrm{Zn}, \mathrm{Fe}$ and manganese concentrations in liver and kidneys were determined by atomic absorption spectrophotometry after dry ashing and solution in dilute hydrochloric acid. These minerals, with the exception of $\mathrm{Mn}$, were also measured in breast muscle. The lipid content of liver samples was measured using the method of Folch et al. (1957).

The results were subjected to analysis of variance and $\log$ transformations were carried out for those variables which exhibited variance heterogeneity.

\section{RESULTS}

Since the determined dietary $\mathrm{Cu}$ values were close to the calculated values, the latter values have been used in presenting the results.

Mean daily food intake, body-weight change and egg production results are shown in Table I. All were significantly depressed $(P<0.00 \mathrm{I})$ by dietary added $\mathrm{Cu}$ level. Bodyweight change and egg production were significantly affected by time on the diet (both $P<0.001$ ) and showed a significant diet $\times$ time interaction (both $P<0.00 \mathrm{I}$ ). Mean egg weight was unaffected either by the level of added $\mathrm{Cu}$ or time on the experimental diets. The over-all mean ( \pm SEM) egg weight was $5 \mathrm{I} \cdot 0 \pm 0.03 \mathrm{~g}$.

Table 2 gives the blood $\mathrm{Hb}$ and PCV values and the serum $\mathrm{Cu}$ and AAT levels. These were significantly affected by the level of $\mathrm{Cu}$ supplementation (all $P<0.00 \mathrm{I}$ ). The principal effect on the blood $\mathrm{Hb}, \mathrm{PCV}$ and serum AAT was an increase at the higher levels of addition. There was apparently an increase in serum $\mathrm{Cu}$ concentration at the intermediate levels of Cu addition.

The mean fresh weights of liver, kidneys, oviduct, ovary and gizzard, expressed as $\mathrm{g} / \mathrm{kg}$ body-weight, are presented in Table 3. As the level of $\mathrm{Cu}$ supplementation increased liver fresh weight $/ \mathrm{kg}$ body-weight decreased and the effect became significant $(P<0.00 \mathrm{I})$ when I000 and $2000 \mathrm{mg}$ added $\mathrm{Cu} / \mathrm{kg}$ diet were fed. The period of time on $\mathrm{Cu}$-supplemented diets did not show an over-all significant effect on liver fresh weight/kg body-weight. Kidney 
Table I. Mean daily food intake, body-weight change and egg number for laying hens given control and $\mathrm{Cu}$-supplemented diets

(Mean values for six observations)

\begin{tabular}{|c|c|c|c|c|c|c|c|c|c|}
\hline \multirow{2}{*}{$\begin{array}{l}\text { Dietary } \\
\text { added Cu } \\
(\mathrm{mg} / \mathrm{kg})\end{array}$} & \multicolumn{5}{|c|}{ Days on experiment } & \multicolumn{4}{|c|}{$\begin{array}{c}\text { Statistical } \\
\text { significance of effect }\end{array}$} \\
\hline & 3 & 6 & 12 & 24 & 48 & SEM & Diet & Time & Diet $\times$ time \\
\hline \multicolumn{10}{|c|}{ Daily food intake (g) } \\
\hline 0 & 107 & 109 & II I & 105 & 107 & $4 \cdot 8$ & $* * *$ & NS & NS \\
\hline 250 & 117 & 107 & 105 & 106 & 103 & & & & \\
\hline 500 & 74 & 87 & 79 & 87 & 90 & & & & \\
\hline 1000 & 35 & 38 & 54 & 51 & 56 & & & & \\
\hline 2000 & 19 & 24 & 31 & 32 & 26 & & & & \\
\hline \multicolumn{10}{|c|}{ Daily body-wt change (g) } \\
\hline 0 & 0.6 & $3 \cdot 3$ & $2 \cdot 7$ & $2 \cdot 4$ & $1 \cdot 5$ & $2 \cdot 94$ & **** & *** & $* * *$ \\
\hline 250 & 4.7 & $6 \cdot 3$ & $1 \cdot 5$ & $2 \cdot \mathbf{I}$ & $1 \cdot 3$ & & & & \\
\hline 500 & $-16 \cdot 1$ & $-6 \cdot 8$ & $-6 \cdot 9$ & $-3 \cdot 5$ & $-1 \cdot 1$ & & & & \\
\hline 1000 & -37.5 & $-32 \cdot 2$ & $-9 \cdot 2$ & $-7 \cdot 7$ & $-3 \cdot I$ & & & & \\
\hline 2000 & $-63 \cdot 1$ & $-35 \cdot 8$ & $-19 \cdot 3$ & -10.8 & -10.3 & & & & \\
\hline \multicolumn{10}{|c|}{ Daily egg number } \\
\hline 0 & $\mathbf{I} \cdot \mathbf{I}$ & I $\cdot 0$ & 0.9 & 0.8 & 0.9 & 0.06 & $* * *$ & *** & **** \\
\hline 250 & 0.9 & $1 \cdot \mathbf{I}$ & 0.9 & 0.9 & 0.9 & & & & \\
\hline 500 & $I \cdot 0$ & I.O & 0.9 & 0.9 & 0.7 & & & & \\
\hline 1000 & 0.8 & 0.8 & 0.4 & 0.4 & 0.2 & & & & \\
\hline 2000 & 0.8 & 0.7 & 0.4 & 0.2 & O.I & & & & \\
\hline
\end{tabular}

fresh weight $/ \mathrm{kg}$ body-weight was significantly depressed by level of added $\mathrm{Cu}(P<0.00 \mathrm{I})$, the period of time on the diets $(P<0.05)$ and the interaction between $\mathrm{Cu}$ level and time was also significant $(P<0.01)$.

The oviduct and ovary fresh weight/ $\mathrm{kg}$ body-weight were depressed and gizzard fresh weight $/ \mathrm{kg}$ body-weight increased by level of added $\mathrm{Cu}$ (all $P<0.00 \mathrm{I}$ ) and period of time on the diets. There was also a diet $\times$ time interaction for the weights of all three organs (all $P<0.001$ ).

The concentrations of $\mathrm{Cu}$ in the liver, kidneys and breast muscle are shown in Table 4 together with the liver lipid concentration. The concentrations of $\mathrm{Cu}$ in the livers of birds receiving diets supplemented with $500-2000 \mathrm{mg} \mathrm{Cu} / \mathrm{kg}$ were significantly higher $(P<0.00 \mathrm{I})$ than those of the birds receiving o or $250 \mathrm{mg}$ added $\mathrm{Cu}$. These higher $\mathrm{Cu}$ concentrations in the livers were apparent after only $3 \mathrm{~d}$ on $\mathrm{Cu}$-supplemented diets and continued to increase up to I2, 24 and $48 \mathrm{~d}$ for the 500 , I000 and $2000 \mathrm{mg} \mathrm{Cu} / \mathrm{kg}$ supplemented diets respectively. The period of time on diet and interaction effects were significant (both $P<0.001$ ). The time effect was apparently due to the responses at the 1000 and $2000 \mathrm{mg} / \mathrm{kg}$ levels of added $\mathrm{Cu}$. By $48 \mathrm{~d}$, the liver $\mathrm{Cu}$ concentration of birds receiving $2000 \mathrm{mg}$ added $\mathrm{Cu} / \mathrm{kg}$ was $1790 \mu \mathrm{g} / \mathrm{g}$ dry matter compared with $74 \mu \mathrm{g} \mathrm{Cu} / \mathrm{g}$ DM after $3 \mathrm{~d}$ on this diet. When compared with the pre-experimental control birds this represents an increase in liver $\mathrm{Cu}$ of approximately $16000 \%$. The effects of diet on Cu levels in kidneys and breast muscle were less marked although the trends were the same as for liver. The results suggest the breast $\mathrm{Cu}$ concentration in DM to be maximum in the region of $500 \mathrm{mg}$ added $\mathrm{Cu} / \mathrm{kg}$ diet. Liver lipid concentration was significantly reduced by level of added $\mathrm{Cu}$ and period of time on the diets (both $P<0.001$ ). There was a highly significant diet $\times$ time interaction.

Values for liver, kidney and breast muscle mineral concentration, excluding $\mathrm{Cu}$, are given 
Table 2. Blood haemoglobin $(H b)$, packed cell volume (PCV), serum copper and aspartate aminotransferase ( $A A T$; EC 2.6. I I) of laying hens given control and $C u$-supplemented diets

\begin{tabular}{|c|c|c|c|c|c|c|c|c|c|c|}
\hline \multirow{2}{*}{$\begin{array}{c}\text { Dietary } \\
\text { added } \\
\mathrm{Cu} \\
(\mathrm{m} / \mathrm{kg})\end{array}$} & \multicolumn{7}{|c|}{ (Mean values for six observations) } & \multicolumn{3}{|c|}{$\begin{array}{c}\text { Statistical } \\
\text { significance of effect }\end{array}$} \\
\hline & 0 & 3 & 6 & 12 & 24 & 48 & SEM & Diet & Time & Diet $\times$ ti.ne \\
\hline $\begin{array}{r}0 \\
250 \\
500 \\
1000 \\
2000\end{array}$ & $87 \cdot 6$ & $\begin{array}{l}84.2 \\
89.0 \\
90.0 \\
88.5 \\
97.0\end{array}$ & $\begin{array}{l}\text { Blood } \\
95 \cdot 3 \\
81 \cdot 0 \\
81 \cdot 5 \\
86 \cdot 5 \\
90 \cdot 0\end{array}$ & $\begin{array}{c}b(g / 1) \\
83.0 \\
79.5 \\
77.7 \\
86.5 \\
87.0\end{array}$ & $\begin{array}{l}78.4 \\
84.7 \\
76.8 \\
78.2 \\
93.5\end{array}$ & $\begin{array}{l}89.0 \\
80.3 \\
78.8 \\
91.8 \\
90.0\end{array}$ & $3 \cdot 83$ & $* * *$ & $\bullet$ & NS \\
\hline $\begin{array}{r}0 \\
250 \\
500 \\
1000 \\
2000\end{array}$ & 0.264 & $\begin{array}{l}0.254 \\
0.273 \\
0.278 \\
0.290 \\
0.300\end{array}$ & $\begin{array}{l}\text { Blooc } \\
0.283 \\
0.260 \\
0.257 \\
0.295 \\
0.277\end{array}$ & $\begin{array}{l}\text { PCV } \\
0.267 \\
0.250 \\
0.247 \\
0.282 \\
0.268\end{array}$ & $\begin{array}{l}0.242 \\
0.263 \\
0.237 \\
0.258 \\
0.290\end{array}$ & $\begin{array}{l}0.275 \\
0.262 \\
0.258 \\
0.272 \\
0.270\end{array}$ & 0.0108 & *** & $\bullet$ & NS \\
\hline $\begin{array}{r}0 \\
250 \\
500 \\
1000 \\
2000\end{array}$ & 253 & $\begin{array}{l}255 \\
267 \\
320 \\
213 \\
225\end{array}$ & $\begin{array}{l}\text { Serum } \\
257 \\
262 \\
272 \\
282 \\
278\end{array}$ & $\begin{array}{l}u(\mu \mathrm{g} / \mathrm{l}) \\
260 \\
293 \\
262 \\
220 \\
252\end{array}$ & $\begin{array}{l}330 \\
380 \\
360 \\
253 \\
232\end{array}$ & $\begin{array}{l}268 \\
353 \\
285 \\
235 \\
288\end{array}$ & $28 \cdot 5$ & $* * *$ & 中 & NS \\
\hline $\begin{array}{r}0 \\
250 \\
500 \\
1000 \\
2000\end{array}$ & 178 & $\begin{array}{l}180 \\
173 \\
173 \\
202 \\
204\end{array}$ & $\begin{array}{l}\text { Serum A } \\
\text { I } 49 \\
164 \\
172 \\
229 \\
261\end{array}$ & $\begin{array}{l}T(i . u . \dagger / l) \\
187 \\
196 \\
186 \\
193 \\
188\end{array}$ & $\begin{array}{l}185 \\
179 \\
206 \\
180 \\
208\end{array}$ & $\begin{array}{l}213 \\
178 \\
165 \\
207 \\
220\end{array}$ & 15.5 & $* * *$ & NS & $* *$ \\
\hline
\end{tabular}

in Table 5. The effects of diet and time on the levels of liver $\mathrm{Zn}$ were significant and there was an interaction (all $P<0.001$ ). After 3 and $6 \mathrm{~d}$ on diets supplemented with 1000 and $2000 \mathrm{mg} \mathrm{Cu} / \mathrm{kg}$, the liver $\mathrm{Zn}$ concentrations were significantly higher $(P<0.00 \mathrm{I})$ than for those in the control and two lower-Cu treatment groups. However, after $6 \mathrm{~d}$ the effect was, in most instances, no longer apparent. The $\mathrm{Zn}$ concentrations in kidneys and breast muscle did not show either a diet or time effect, and mean values for each treatment are not presented in Table 5. The over-all mean ( \pm SEM) $\mathrm{Zn}$ values for kidney and breast muscle were $12 \mathrm{I} \cdot 2 \pm 5 \cdot 50$ and $3 \mathrm{I} \cdot 3 \pm \mathrm{I} \cdot \mathrm{I} 3 \mu \mathrm{g} / \mathrm{g}$ DM respectively.

Liver Fe concentrations were increased by $\mathrm{Cu}$ treatment $(P<0.00 \mathrm{I})$. The effect was present by $12 \mathrm{~d}$ at the $2000 \mathrm{mg} / \mathrm{kg}$ level of $\mathrm{Cu}$ addition and by $24 \mathrm{~d}$ the effect was also evident at the $1000 \mathrm{mg} / \mathrm{kg}$ level. Kidney Fe concentration was affected by dietary added $\mathrm{Cu}$ $(P<0.00 \mathrm{I})$, the tendency being for kidney $\mathrm{Fe}$ to be increased at the highest level of dietary $\mathrm{Cu}$ addition at 24 and $48 \mathrm{~d}$. Breast muscle Fe showed an increase with the period of time on the diets $(P<0.001)$ but dietary added $\mathrm{Cu}$ had no effect.

Liver Mn was increased $(P<0.001)$ and kidney $\mathrm{Mn}$ decreased $(P<0.05)$ with level of added dietary $\mathrm{Cu}$.

Table 6 shows the mean total $\mathrm{Zn}, \mathrm{Fe}$ and $\mathrm{Mn}$ contents of liver and the $\mathrm{Cu}, \mathrm{Zn}$ and $\mathrm{Mn}$ contents of the kidneys. Since the statistical effects for total $\mathrm{Cu}$ content of liver are the same 
Table 3. Mean fresh weights ( $\mathrm{g} / \mathrm{kg}$ body-weight) of liver, kidneys, oviduct, ovary and gizzard of laying hens given control and copper-supplemented diets

(Mean values for six observations)

\begin{tabular}{|c|c|c|c|c|c|c|c|c|c|c|}
\hline \multirow{2}{*}{$\begin{array}{c}\text { Dietary } \\
\text { added Cu } \\
(\mathrm{mg} / \mathrm{kg})\end{array}$} & \multicolumn{6}{|c|}{ Days on experiment } & & \multicolumn{3}{|c|}{$\begin{array}{c}\text { Statistical } \\
\text { significance of effect }\end{array}$} \\
\hline & 0 & 3 & 6 & 12 & 24 & 48 & SEM & Diet & Time & Diet $\times$ time \\
\hline \multicolumn{11}{|c|}{ Liver } \\
\hline 0 & $22 \cdot I$ & $23 \cdot 9$ & $25 \cdot 4$ & $25 \cdot 2$ & $22 \cdot 7$ & $24 \cdot 9$ & $1 \cdot 29$ & $\# * *$ & NS & NS \\
\hline 250 & & $24 \cdot 0$ & $22 \cdot 3$ & $24 \cdot 5$ & $25 \cdot 8$ & $22 \cdot 4$ & & & & \\
\hline 500 & & $21 \cdot 5$ & $23 \cdot 0$ & $24 \cdot 8$ & $23 \cdot 9$ & $22 \cdot 4$ & & & & \\
\hline 1000 & & $18 \cdot 2$ & $19 \cdot 2$ & $18 \cdot 4$ & $19 \cdot 9$ & $17 \cdot 3$ & & & & \\
\hline 2000 & & $17 \cdot 5$ & $15 \cdot 4$ & 15.8 & $14 \cdot 2$ & .13 .4 & & & & \\
\hline \multicolumn{11}{|c|}{ Kidneys } \\
\hline 0 & $6 \cdot 3$ & $7 \cdot 0$ & $6 \cdot 6$ & 6.6 & $6 \cdot I$ & 6.7 & 0.31 & $* * *$ & $*$ & $* *$ \\
\hline 250 & & 6.6 & 6.4 & 6.9 & $7 \cdot 2$ & $6 \cdot 6$ & & & & \\
\hline 500 & & $7 \cdot 0$ & $7 \cdot i$ & $7 \cdot 2$ & $7 \cdot 1$ & $7 \cdot 3$ & & & & \\
\hline 1000 & & $8 \cdot 0$ & $7 \cdot 1$ & $6 \cdot 2$ & $6 \cdot 7$ & $6 \cdot 3$ & & & & \\
\hline 2000 & & $6 \cdot 5$ & $6 \cdot 9$ & $6 \cdot 3$ & $6 \cdot 0$ & $5 \cdot 3$ & & & & \\
\hline \multicolumn{11}{|c|}{ Oviduct } \\
\hline 0 & $34 \cdot 3$ & $41 \cdot 2$ & $37 \cdot 4$ & $38 \cdot 4$ & $35 \cdot 8$ & 35.0 & $2 \cdot 43$ & $* * *$ & $* * *$ & $* * *$ \\
\hline 250 & & $34 \cdot 7$ & 40.8 & $34 \cdot 3$ & 36.9 & $36 \cdot 2$ & & & & \\
\hline 500 & & $34 \cdot 0$ & $36 \cdot 2$ & $36 \cdot 7$ & $36 \cdot 3$ & $35 \cdot 3$ & & & & \\
\hline 1000 & & $37 \cdot 2$ & $28 \cdot 8$ & $19 \cdot 1$ & $26 \cdot 0$ & 6.9 & & & & \\
\hline 2000 & & $3 I \cdot 4$ & 18.8 & $11 \cdot 4$ & $3 \cdot 3$ & I $\cdot 8$ & & & & \\
\hline \multicolumn{11}{|c|}{ Ovary } \\
\hline 0 & $27 \cdot 1$ & $29 \cdot 4$ & 25.4 & $30 \cdot 6$ & 29.0 & $27 \cdot 7$ & 2.53 & $* * *$ & $* * *$ & $* * *$ \\
\hline 250 & & $27 \cdot I$ & $30 \cdot 3$ & $29 \cdot 4$ & 28.8 & $25 \cdot 3$ & & & & \\
\hline 500 & & $26 \cdot 0$ & $29 \cdot 5$ & $24 \cdot 2$ & 25.8 & $26 \cdot 7$ & & & & \\
\hline I000 & & 36.9 & $19 \cdot 1$ & $12 \cdot 0$ & $17 \cdot 1$ & I I I I & & & & \\
\hline 2000 & & 25.9 & 12.5 & $5 \cdot 6$ & $2 \cdot 6$ & $\mathbf{I} \cdot \mathbf{I}$ & & & & \\
\hline \multicolumn{11}{|c|}{ Gizzard } \\
\hline 0 & $12 \cdot I$ & $14^{\circ} 0$ & 13.5 & 13.8 & $15 \cdot 2$ & $12 \cdot 0$ & 0.79 & $* * *$ & $* *$ & $* * *$ \\
\hline 250 & & 14.7 & 14.9 & 14.7 & 13.7 & 13.2 & & & & \\
\hline 500 & & 14.6 & 16.6 & 154 & 157 & $14 \cdot 2$ & & & & \\
\hline 1000 & & 16.9 & $17 \cdot 7$ & 16.7 & $17 \cdot 7$ & 18.2 & & & & \\
\hline 2000 & & 15.3 & $16 \cdot 3$ & 19.4 & 19.9 & 26.7 & & & & \\
\hline
\end{tabular}

as those for liver $\mathrm{Cu}$ concentration (Table 4 ) the treatment mean results are not presented. After I $2 \mathrm{~d}$ of feeding the two highest levels of $\mathrm{Cu}$-supplemented diets, total liver $\mathrm{Zn}$ was significantly decreased $(P<0.01)$ and this decrease was maintained up to $48 \mathrm{~d}$. Total liver Fe contents were significantly increased $(P<0.001)$ by feeding diets supplemented with 1000 and $2000 \mathrm{mg} \mathrm{Cu} / \mathrm{kg}$ for $48 \mathrm{~d}$. Liver $\mathrm{Mn}$ was decreased by diet and time $(P<0.00 \mathrm{I}$ and $P<0.05$ respectively). Total kidney $\mathrm{Cu}$ content was not significantly affected by $\mathrm{Cu}$ supplementation. There was a time effect $(P<0.05)$ and this was quite evident at 24 and $48 \mathrm{~d}$. Total $\mathrm{Zn}$ contents of kidneys of control birds after $6 \mathrm{~d}$ feeding were significantly $(P<0.05)$ higher than those levels for any other birds at any time during the $\mathrm{Cu}$ treatment. Kidney $\mathrm{Mn}$ was significantly decreased by increasing $\mathrm{Cu}$ level in the $\operatorname{diet}(P<0.001)$ and period of time on the diets $(P<0.01)$, and there was a diet $\times$ time interaction $(P<$ 0.05). Total kidney Fe levels were unaffected by $\mathrm{Cu}$ supplementation of the diets, the overall mean $( \pm$ SEM) value being $798 \pm 60 \cdot 0 \mu \mathrm{g}$.

Histological changes observed in the liver and kidney of $\mathrm{Cu}$-treated hens were similar 


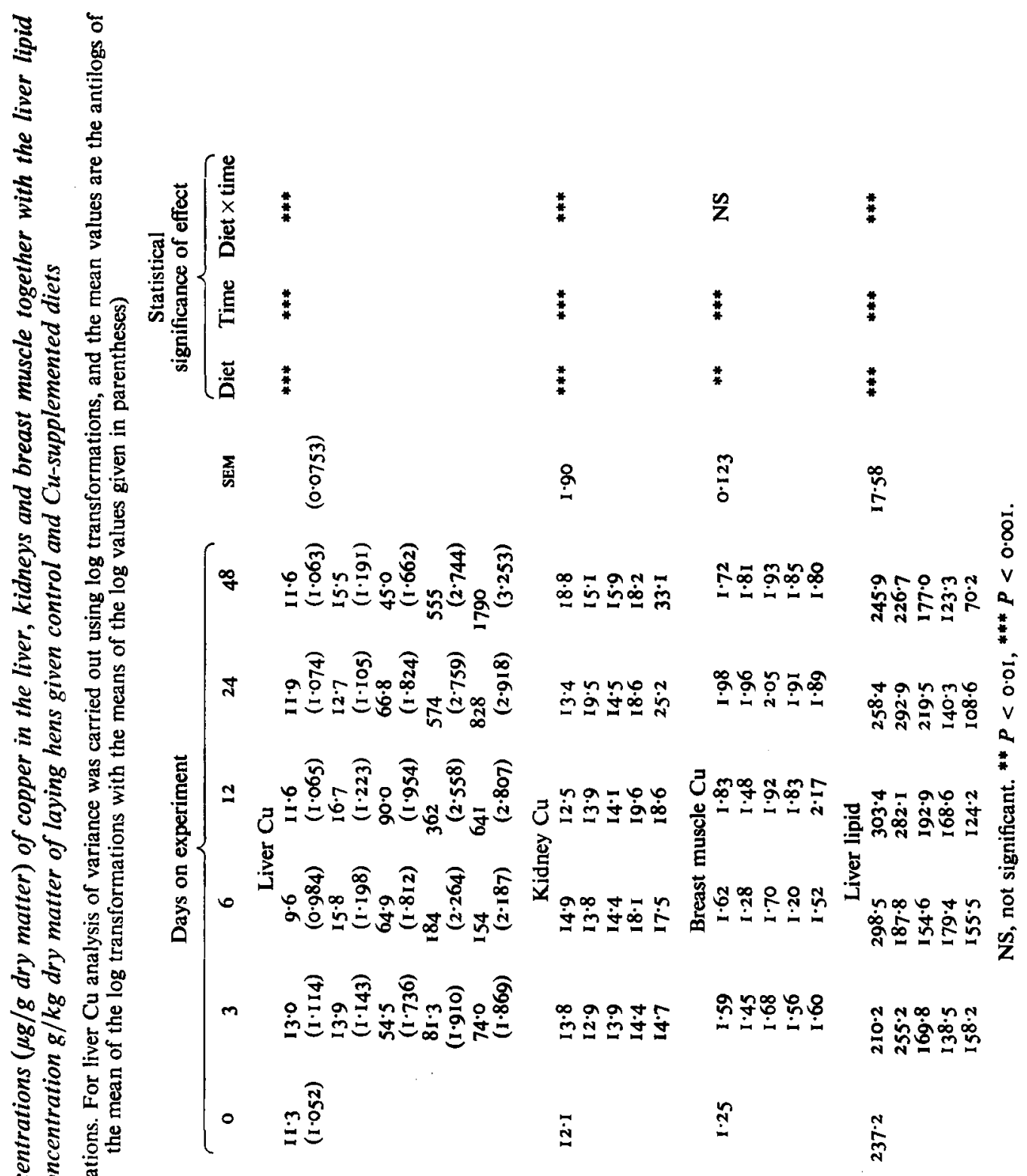

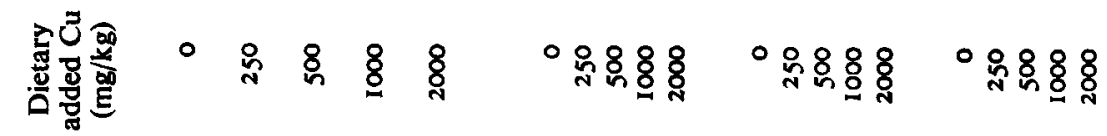


Table 5. The mean concentration ( $\mu \mathrm{g} / \mathrm{g}$ dry matter) of zinc in liver, of iron in liver, kidney and breast muscle and of manganese in liver and kidney of laying hens given control and $\mathrm{Cu}$ supplemented diets

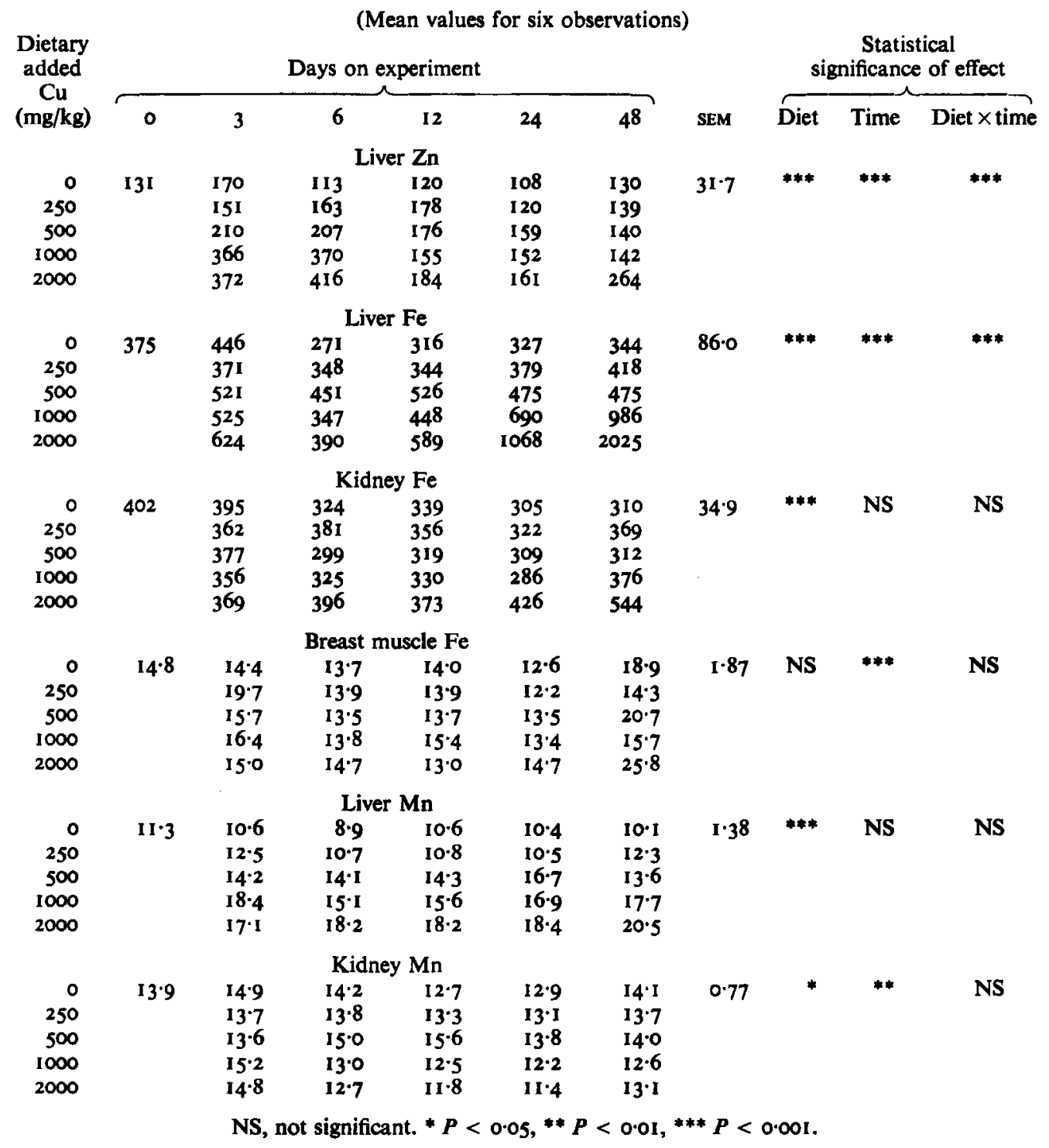

to those in control birds. The spleen was apparently unaffected in any of the treatment groups. Birds on the two highest $\mathrm{Cu}$ treatments exhibited considerable thickening and damage to the gizzard lining. Microscopic examination of the gizzards revealed focal changes in the koilin layer.

The $\mathrm{Cu}$-staining procedure failed to reveal the presence of $\mathrm{Cu}$ in liver, kidney or spleen, but $\mathrm{Cu}$-staining was evident in the koilin layer and this effect increased with the level of added dietary $\mathrm{Cu}$. 
Table 6. The mean total (mg) zinc, iron and manganese contents of liver, and copper $(\mu \mathrm{g})$, $\mathrm{Zn}(\mathrm{mg})$ and $\mathrm{Mn}(\mu \mathrm{g})$ contents of kidneys of laying hens given control and $\mathrm{Cu}$-supplemented diets

\begin{tabular}{|c|c|c|c|c|c|c|c|c|c|c|}
\hline \multirow{2}{*}{$\begin{array}{l}\text { Dietary } \\
\text { added Cu } \\
(\mathrm{mg} / \mathrm{kg})\end{array}$} & \multicolumn{7}{|c|}{$\begin{array}{l}\text { (Mean values for six observations) } \\
\text { Days on experiment }\end{array}$} & \multicolumn{3}{|c|}{$\begin{array}{c}\text { Statistical } \\
\text { significance of effect }\end{array}$} \\
\hline & o & 3 & 6 & 12 & 24 & 48 & SEM & Diet & Time & $\overline{\text { Diet } \times \text { tinne }}$ \\
\hline \multicolumn{11}{|c|}{ Liver $\mathbf{Z n}$} \\
\hline 0 & $1 \cdot 51$ & $1 \cdot 8 I$ & $1 \cdot 49$ & $1 \cdot 56$ & $1 \cdot 20$ & $1 \cdot 52$ & 0.303 & NS & $* * *$ & ** \\
\hline 250 & & $1 \cdot 79$ & 1.66 & $2 \cdot 50$ & $1 \cdot 58$ & $1 \cdot 43$ & & & & \\
\hline 500 & & $1 \cdot 73$ & 1.83 & $1 \cdot 78$ & 1.60 & $1 \cdot 19$ & & & & \\
\hline 1000 & & $2 \cdot 59$ & 2.92 & $1 \cdot 22$ & $1 \cdot 13$ & 0.93 & & & & \\
\hline 2000 & & $2 \cdot 47$ & 2.42 & 1.06 & 0.82 & 0.99 & & & & \\
\hline \multicolumn{11}{|c|}{ Liver Fe } \\
\hline 0 & $4 \cdot 23$ & 5.01 & 3.51 & 4.05 & 3.64 & $4 \cdot 11$ & 0.558 & NS & $* * *$ & $* * *$ \\
\hline 250 & & $4 \cdot 46$ & 3.52 & 4.52 & 4.95 & $4 \cdot 32$ & & & & \\
\hline 500 & & $4 \cdot 30$ & $4 \cdot 04$ & 5.03 & $4 \cdot 87$ & $4 \cdot 09$ & & & & \\
\hline 1000 & & 3.67 & 2.75 & $3 \cdot 34$ & $4 \cdot 81$ & $6 \cdot 15$ & & & & \\
\hline 2000 & & $4 \cdot 14$ & $2 \cdot 22$ & $3 \cdot 32$ & $5 \cdot 28$ & $7 \cdot 60$ & & & & \\
\hline \multicolumn{11}{|c|}{ Liver $\mathbf{M n}$} \\
\hline 0 & 0.131 & 0.112 & 0.115 & 0.135 & 0.117 & 0.117 & 0.0108 & $* * *$ & * & NS \\
\hline 250 & & $0 \cdot 146$ & 0.109 & 0.137 & 0.137 & $0 \cdot 123$ & & & & \\
\hline 500 & & 0.117 & 0.126 & $0.13^{8}$ & 0.172 & 0.117 & & & & \\
\hline 1000 & & 0.130 & 0.115 & 0.122 & 0.124 & 0.114 & & & & \\
\hline 2000 & & 0.114 & 0.110 & 0.102 & 0.093 & 0.077 & & & & \\
\hline \multicolumn{11}{|c|}{ Kidney Cu } \\
\hline 0 & $28 \cdot 8$ & $33 \cdot 9$ & $35 \cdot 4$ & $28 \cdot 7$ & $30 \cdot 3$ & $49 \cdot 0$ & $4 \cdot 55$ & NS & $*$ & NS \\
\hline 250 & & $3 I \cdot 7$ & $32 \cdot 5$ & $38 \cdot 1$ & 50.4 & $38 \cdot 0$ & & & & \\
\hline 500 & & $32 \cdot 3$ & $33 \cdot 8$ & $33 \cdot 2$ & $34 \cdot 9$ & $36 \cdot 5$ & & & & \\
\hline 1000 & & $36 \cdot 2$ & $39 \cdot 9$ & 40.7 & $36 \cdot 5$ & $34 \cdot 6$ & & & & \\
\hline 2000 & & $3 I \cdot I$ & $38 \cdot 5$ & $34 \cdot 6$ & $42 \cdot 8$ & $5 I \cdot 4$ & & & & \\
\hline \multicolumn{11}{|c|}{ Kidney Zn } \\
\hline 0 & 0.25 & 0.47 & 0.59 & 0.26 & 0.25 & 0.30 & 0.077 & - & NS & NS \\
\hline 250 & & 0.29 & 0.27 & 0.24 & 0.29 & 0.32 & & & & \\
\hline 500 & & 0.29 & 0.25 & 0.22 & 0.28 & 0.25 & & & & \\
\hline 1000 & & 0.30 & 0.26 & 0.23 & 0.21 & 0.21 & & & & \\
\hline 2000 & & 0.25 & 0.31 & 0.19 & O. & 0.20 & & & & \\
\hline \multicolumn{11}{|c|}{ Kidney Mn } \\
\hline 0 & $32 \cdot 7$ & $36 \cdot 6$ & $33 \cdot 6$ & 30.5 & 29.9 & $37 \cdot 1$ & $2 \cdot 38$ & $* * *$ & $* *$ & * \\
\hline 250 & & 33.8 & $32 \cdot 3$ & $32 \cdot 3$ & $34 \cdot 1$ & $34 \cdot 3$ & & & & \\
\hline 500 & & $31 \cdot 6$ & $35 \cdot I$ & $36 \cdot 3$ & $33 \cdot 3$ & $31 \cdot 9$ & & & & \\
\hline 1000 & & $37 \cdot 0$ & $28 \cdot 7$ & 25.9 & $24 \cdot 1$ & $24 \cdot 4$ & & & & \\
\hline 2000 & & $31 \cdot 8$ & $27 \cdot 4$ & $2 I \cdot 9$ & 19.4 & $20 \cdot 0$ & & & & \\
\hline
\end{tabular}

\section{DISCUSSION}

The laying hen has been shown to be extremely tolerant to excessively high levels of added $\mathrm{Cu}$ (Jackson, I977; Jackson et al. 1979) and this has been confirmed in the present experiment.

The significant reductions in body-weight gain and food intake at the high levels of added dietary $\mathrm{Cu}$ agree with previous results from this laboratory (Jackson, 1977; Jackson et al. 1979). The reduced weight gains in the current work were apparent after only $3 \mathrm{~d}$ on the $\mathrm{Cu}$-supplemented diets although the improved food intake at about $250 \mathrm{mg}$ added $\mathrm{Cu} / \mathrm{kg}$ diet reported previously (Jackson, 1977; Jackson et al. 1979) was not observed. 
The reduction or cessation of egg production in response to high levels of added dietary $\mathrm{Cu}$ is in agreement with previous findings (Jackson, 1977; Griminger, 1977; Jackson et al. 1979). At the highest level of added $\mathrm{Cu}$, egg laying ceased after $5 \mathrm{~d}$ and at $1000 \mathrm{mg}$ added $\mathrm{Cu} / \mathrm{kg}$ it was only spasmodic after $5 \mathrm{~d}$. Calculation of the metabolizable energy and protein requirements for maintenance and production (Agricultural Research Council, 1975) show that the decreased food intake would explain the reduction in egg numbers. This effect is similar to that in the broiler, where paired-feeding trials showed growth depression to be due to reduced food intake (Fisher et al. 1972). However, it is possible in experiments with the laying hen that the added dietary $\mathrm{Cu}$ may have influenced the hormonal control of egg production.

In the present experiment serum $\mathrm{Cu}$ was increased by 250 and $500 \mathrm{mg}$ added $\mathrm{Cu} / \mathrm{kg}$ and decreased by the two highest levels compared with the control birds. The Hb and PCV levels were significantly increased by $2000 \mathrm{mg}$ added $\mathrm{Cu} / \mathrm{kg}$, and increased serum AAT - which accompanies cellular breakdown and is often indicative of liver dysfunction - was found at the higher levels of dietary added Cu. Jackson (1977) found that giving diets supplemented with up to $1920 \mathrm{mg} \mathrm{Cu} / \mathrm{kg}$ did not affect blood $\mathrm{Cu}$, but diets with 300 and $400 \mathrm{mg}$ added $\mathrm{Cu} / \mathrm{kg}$ significantly increased blood Cu levels (Jackson et al. I979). In general the other blood and serum observations agree with those found at high and intermediate levels of $\mathrm{CuSO}_{4}$ addition by Jackson (1977) and Jackson et al. (1979) respectively.

The significant decreases in liver, kidney, oviduct and ovary fresh weights, expressed as $\mathrm{g} / \mathrm{kg}$ body-weight, resulting from added dietary $\mathrm{Cu}$ were expected in the light of previous results by the present authors (Jackson, 1977; Jackson et al. 1979). In the present experiment fresh liver weights per unit body-weight were reduced as a result of giving diets supplemented with 1000 and $2000 \mathrm{mg} \mathrm{Cu} / \mathrm{kg}$. Since, after $48 \mathrm{~d}$ on the diet with $2000 \mathrm{mg}$ added $\mathrm{Cu} / \mathrm{kg}$, oviduct and ovary weights were extremely small, it is obvious that egg production must have ceased completely by this time.

The increase in gizzard fresh weight/ $\mathrm{kg}$ body-weight with added dietary $\mathrm{Cu}$ has been observed before in the laying hen (Jackson et al. 1979). The thickening of the gizzard lining is in accord with the effects reported by Fisher et al. (1973). The increase in Cu concentration in the gizzard lining agrees with the quantitative observations of Cunningham (1931), Starcher (1969) and Fisher et al. (1973).

Liver $\mathrm{Cu}$ concentration (Table 4) was significantly increased by high levels of added dietary $\mathrm{Cu}$ and unaffected by $250 \mathrm{mg} \mathrm{Cu} / \mathrm{kg}$. The rate of accumulation of $\mathrm{Cu}$ in liver was rapid, substantial increases being apparent after only $3 \mathrm{~d}$ of $\mathrm{Cu}$ treatment. The liver $\mathrm{Cu}$ levels continued to increase for $48 \mathrm{~d}$ on the highest $\mathrm{Cu}$ treatment but, with the 500 and $1000 \mathrm{mg}$ added $\mathrm{Cu} / \mathrm{kg}$, a maximum was reached after $\mathrm{I} 2$ and $24 \mathrm{~d}$ respectively. Jackson et al. (1979) have reported that the laying hen appears to exhibit a threshold level of $\mathrm{Cu}$ intake between 600 and $800 \mathrm{mg}$ added $\mathrm{Cu} / \mathrm{kg}$ diet, above which accumulation occurs in the liver. In the current 'experiment this threshold was found to occur between 250 and $500 \mathrm{mg}$ added $\mathrm{Cu} / \mathrm{kg}$ diet. This threshold effect has been noted in other species. For example, threshold levels of 200 and $50 \mathrm{mg} \mathrm{Cu} / \mathrm{kg}$ diet respectively have been reported for the rat and cotton rat (Milne \& Weswig, 1968) while the value for the pig lies between 70 and I30 $\mathrm{mg} / \mathrm{kg}$ (Ritchie et al. 1963). On a lipid-free basis the effects of diet and time on liver $\mathrm{Cu}$ concentration (not presented) are even more evident. Both dietary added $\mathrm{Cu}$ and time on the diets had a highly significant effect on liver lipid concentration. The results suggest that there is a negative linear relationship between liver lipid concentration and the level of added dietary Cu. This effect is similar to that found by Jackson et al. ( I979) but does not support the observations of Jensen \& Maurice (1978) who found $240 \mathrm{mg}$ added Cu/ $\mathrm{kg}$ diet to cause an increase in liver lipid concentration. The response of liver lipid concentration to time indicates a quadratic relationship over the period of the experiment. 
Although added $\mathrm{Cu}$ had a significant effect on kidney and breast muscle $\mathrm{Cu}$ levels, the increases were of a much lower order than those observed in the liver. Similar results have previously been reported for the laying hen (Jackson et al. 1979) and the broiler (Fisher et al. 1972; Norvell et al. 1974).

Liver $\mathrm{Zn}$ levels (Table 5) were significantly affected by $\mathrm{Cu}$ treatment. There was an indication of an increase on the three highest treatments at 3 and $6 \mathrm{~d}$, this effect being statistically significant on the two highest $\mathrm{Cu}$ treatments. By $\mathrm{I} 2 \mathrm{~d}$ and subsequently this effect was no longer evident, except at $48 \mathrm{~d}$ for the birds receiving $2000 \mathrm{mg} \mathrm{Cu} / \mathrm{kg}$ diet. Fisher et al. (1972), working with broilers, found that liver $\mathrm{Zn}$ levels were increased by diets supplemented with $50 \mathrm{mg} \mathrm{Zn} / \mathrm{kg}$ together with 500 or $750 \mathrm{mg} \mathrm{Cu} / \mathrm{kg}$, but were decreased when dietary $\mathrm{Zn}$ concentration was increased to $200 \mathrm{mg} / \mathrm{kg}$. In the current experiment the dietary $\mathrm{Zn}$ concentration was $136 \mathrm{mg} / \mathrm{kg}$, and evidence suggests that the contribution from the galvanized cages and fittings would be less than $10 \mathrm{mg} \mathrm{Zn/kg} \mathrm{diet} \mathrm{(Mehring} \mathrm{et} \mathrm{al.} \mathrm{1956).} \mathrm{These} \mathrm{results} \mathrm{in}$ the laying hen and broiler suggest an effect not dissimilar to that in the pig, where dietary $\mathrm{Cu}$ had been found to cause a decrease in the incidence of parakeratosis. Also Ritchie et al. (I963) have shown a slight, but not statistically significant tendency for storage of liver $\mathrm{Zn}$ as dietary $\mathrm{Cu}$ level increased. Although Davis (1958) has reported that toxic levels of dietary $\mathrm{Cu}$ result in almost complete elimination of $\mathrm{Zn}$ from the liver of the pig, there is no evidence of a similar effect in the laying hen.

The increased Fe concentration in the liver as a result of the high $\mathrm{Cu}$ treatment is a further indication of differences which exist between the fowl and other species, since in the rat a highly significant inverse correlation has been found between hepatic $\mathrm{Fe}$ and $\mathrm{Cu}$ (Sourkes et al. I968).

The levels of Mn found in the liver agree with those of Mathers \& Hill (I968) for laying hens. The increase in liver Mn concentration is, at first sight, unexpected in light of the dramatic increase in liver $\mathrm{Fe}$ associated with increasing dietary $\mathrm{Cu}$, since $\mathrm{Fe}$ and $\mathrm{Mn}$ show considerable similarity in chemical properties and could reasonably be expected to exhibit antagonism. However, the kidney $\mathrm{Mn}$ levels were decreased by increasing $\mathrm{Cu}$ level, but the effect was only marginal.

With regard to the total content of $\mathrm{Zn}$ in the liver (Table 6) there was no diet effect, and this suggests that the effect on $\mathrm{Zn}$ concentration seen in Table 5 was due to reduction in liver weight. However, the effect on liver Fe would appear to be a true increase in total Fe content and not merely a concentration effect. In the instance of liver $\mathrm{Mn}$ the increased concentration is apparently due to reduced liver weight, since when the $\mathrm{Mn}$ is presented as total content it is significantly decreased by increasing added $\mathrm{Cu}$ in the diet.

The authors thank Dr G. R. Pearson for gross and histological examination of tissues, Dr D. Kilpatrick for statistical analyses and $\mathrm{Mr}$ W. Graham for technical assistance.

\section{REFERENCES}

Agricultural Research Council (1975). The Nutrient Requirements of Farm Livestock No. I, Poultry. London: HM Stationery Office.

Barber, R. S., Braude, R. \& Mitchell, K. G. (1955). Br. J. Nutr. 19, 575.

Bergmeyer, H. U. \& Bernt, E. (1965). In Methods of Enzymatic Analysis, p. 837 [H. U. Bergmeyer, editor]. Weinheim: Verlag Chenie.

Cunningham, I. J. (1931). Biochem. J. 25, 1267.

Davis, G. K. (1958). Soil Sci. 85, 59.

Fisher, C. (1973). Feedstuffis 45, no. 29, 24.

Fisher, C., Laursen-Jones, A. P., Hill, K. J. \& Hardy, W. S. (1973). Br. Poult. Sci. 14, 55.

Fisher, C., Wise, D. \& Filmer, D. G. (1972). I4th Wld's Poult. Congr. Madrid 2, 759.

Folch, J., Lees, N. \& Sloane-Stanley, G. H. (1957). J. biol. Chem. 226, 497.

Griminger, P. (1977). Poult. Sci. 56, 359.

Ichida, T. \& Nobuoka, M. (1969). Clinica chim. Acta 24, 299. 
Jackson, N. (1977). Br. J. Nutr. 38, 93.

Jackson, N., Stevenson, M. H. \& Kirkpatrick, G. McC. (1979). Br. J. Nutr. 42, 253.

Jensen, L. S. \& Maurice, D. V. (1978). Poult. Sci. 57, 166.

Lindquist, R. R. (1969). Archs Path. 87, 370.

Mathers, J. R. \& Hill, R. C. (I968). Br. J. Nutr. 22, 635.

Mehring, A. L., Brumbaugh, J. H. \& Titus, H. W. (1956). Poult. Sci. 35, 956.

Milne, D. H. \& Weswig, P. H. (1968). J. Nutr. 95, 429.

Norvell, M. J., Calvert, C. C., Thomas, M. C. \& Goatcher, W. D. (1974). Poult. Sci. 53, I64I Abstr.

Ritchie, H. D., Leucke, R. W., Baltzer, B. V., Miller, E. R., Ullrey, D. E. \& Hoefer, J. A. (1963). J. Nutr. 79, 117.

Sourkes, T. L., Lloyd, K. \& Birnbaum, H. (1968). Can. J. Biochem. 46, 267.

Starcher, B. C. (1969). J. Nutr. 97, 321 .

Stevenson, M. H. \& Jackson, N. (1979). Proc. Nutr. Soc. 38, 29 A. 